Supporting information for

\title{
Proteomics analysis of cellular BRS3 receptor activation reveals potential mechanism for signal transduction and cell proliferation
}

Lijie Donga , Baohui Zhanga, Lehao Wua ${ }^{a}$ Zhi Shanga, Sha Liua, Xiaoteng Jianga, Huiyu Wang a, Liuyin Fanc, Yan Zhang ${ }^{\mathrm{b},{ }^{*}}$, Hua Xiao a,

* Corresponding Authors:

Prof. Dr. Hua Xiao, Email address: huaxiao@situ.edu.cn

Prof. Dr. Yan Zhang, Email address: zhangyan sjtu@sjtu.edu.cn 
Figure S1. Pearson correlations of three nano-LC-MS/MS technical replicates data.

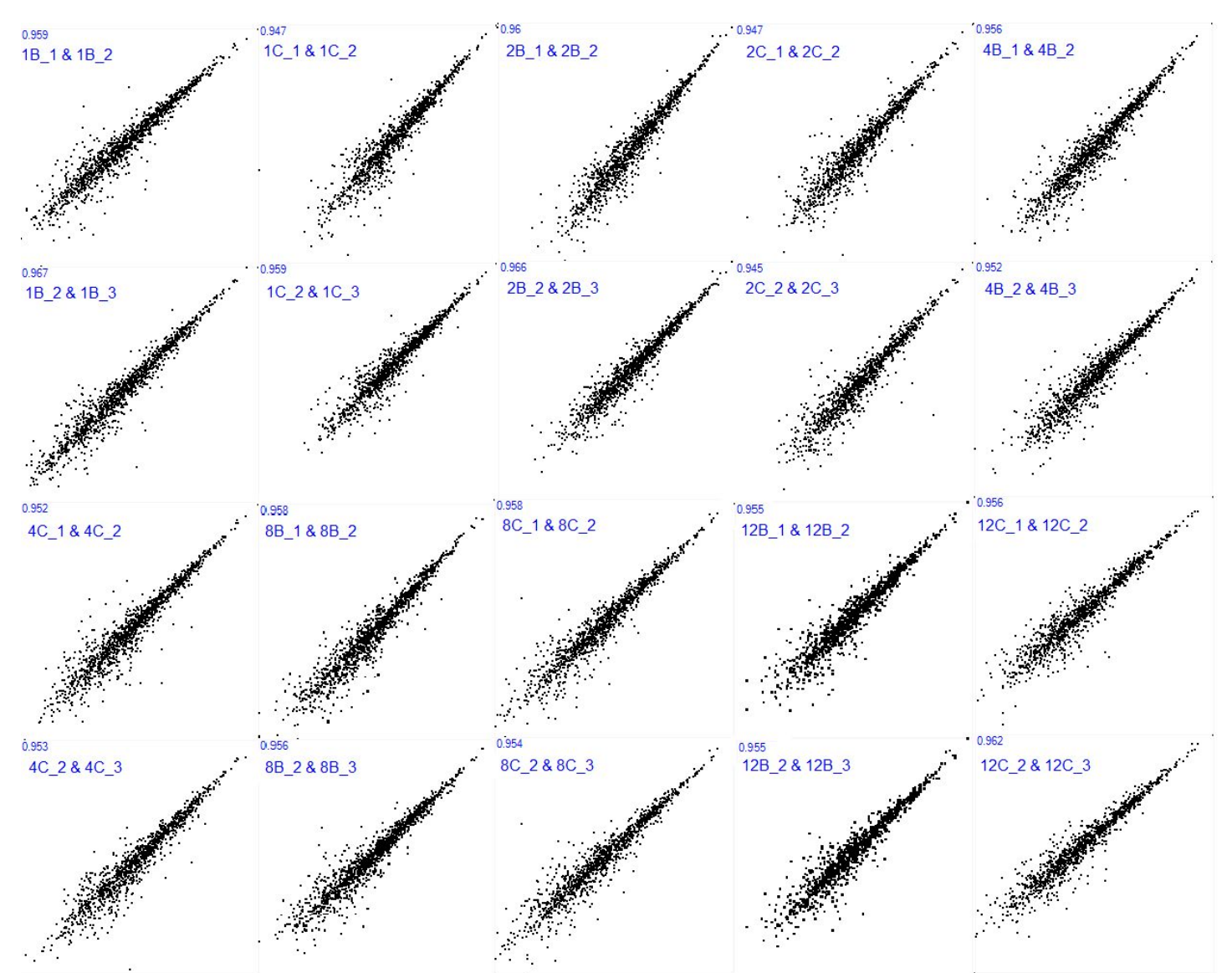


Figure S2. Pearson correlations of two nano-LC-MS/MS biological replicates data.

$0.9271 \mathrm{~B} \& 1 \mathrm{~B}^{\prime}$

$0.8822 B \& 2 B$

$0.8841 \mathrm{C} \& 1 \mathrm{C}^{\prime}$

$0.9232 \mathrm{C} \& 2 \mathrm{C}$
$0.8984 B^{8} \& 4 \mathrm{~B}^{\circ}$

$0.90648^{8} 4 C^{\circ}$

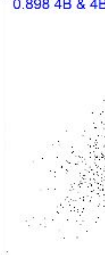

$0.9228 B \& 8 B^{\prime}$
$0.9218 C \& 8 C$
$0.90512 B \& 12 B$

$0.8912 C \& 12 C$ 